\title{
COMPARATIVE ANALISYS OF THREE DIFFERENT DIAGNOSTIC METHODS TO EVALUATE CARIOUS ACTIVITY IN A COMMUNITY BASIS
}

\author{
ANÁLISE COMPARATIVA DE TRÊS MÉTODOS DE DIAGNÓSTICO DE ATIVIDADE \\ CARIOSA EM ÂMBITO COLETIVO
}

Luciana CARDOSO ${ }^{1}$, Lisiane Christoff Corrêa de BARROS ${ }^{2}$, Paulo Floriani KRAMER ${ }^{3}$, Cassiano Kuchenbecker RÖSING ${ }^{4}$, Carolina Covolo da COSTA ${ }^{5}$

1- DDS, MSc, Assistant Professor, Department of Pediatric Dentistry, Lutheran University of Brasil.

2- DDS.

3- DDS, MSc, PHD, Associate Professor, Department of Pediatric Dentistry, Lutheran University of Brasil.

4- DDS, MSc, PHD, Associate Professor, Department of Periodontology, Lutheran University of Brasil and Federal University of Rio Grande do Sul.

5- DDS, MSc, PHD.

Corresponding address: Rua Capitão Cruz, 2137. Montenegro - RS. CEP: 95780-000 - Fone/Fax: (51) 632-1512 - cardosoluciana@hotmail.com

Received: June 26, 2003 - Modification: April 14, 2004 - Accepted: May 10, 2005

\begin{abstract}
$T_{\mathrm{h}}$

I he present research has made a comparison between three distinct methods to evaluate carious activity in a community basis. The studied method was based in a modified DMFS/dmfs index including non-cavitated lesions. Two factors were analyzed: the possible reproduction of the inclusion of carious activity criteria and the presence of bacterial plaque. Thus, the three study groups presented with plaque, after supervised self-performed plaque removal with dental toothbrush and without plaque after professional prophylaxis, which corresponded to three diagnostic methods. The three exams took place one week apart from each other. For this analysis, a modified DMFS/dmfs index was proposed with alterations in diagnostic criteria due to the inclusion of carious activity parameters. The study was performed in a group of 30 children aged 11 years old. According to the results, the diagnostic method for carious activity in the three situations was reproducible and can be considered a proper approach to perform caries diagnosis in a community basis.
\end{abstract}

Uniterms: Dental caries, diagnosis; Pediatric dentistry.

\section{RESUMO}

E

ste trabalho realizou uma comparação entre três métodos distintos para avaliação da atividade cariosa em âmbito coletivo. Os métodos estudados foram baseados em um CPOS/ceos modificado, com inclusão de lesões não cavitadas. Os fatores estudados foram a possibilidade de reprodutibilidade da inclusão de critérios de atividade cariosa, bem como a presença de placa bacteriana. Portanto, os três grupos avaliados apresentavam-se com placa bacteriana; com remoção de placa bacteriana pelo próprio paciente (sob supervisão) com escova dental e sem placa bacteriana, após profilaxia profissional, que correspondiam aos três métodos de diagnóstico. Os três exames foram realizados com intervalo de uma semana entre cada um. Para esta análise, propõe-se um índice CPOS/ceos modificado com alterações nos critérios de diagnóstico através da inclusão de parâmetros de atividade de doença. O estudo foi realizado em um grupo de 30 crianças, com idade de 11 anos. De acordo com os resultados obtidos, os três métodos de diagnóstico de atividade cariosa, na população estudada, demonstraram-se reproduzíveis, podendo ser mais uma forma de adequadamente realizar-se diagnóstico de cárie em nível coletivo.

Unitermos: Cárie dentária, diagnóstico; Odontopediatria. 


\section{INTRODUCTION}

Dental caries is a disease with high prevalence that has affected humankind since the beginning of its existence. From the $18^{\text {th }}$ century on, there was a great increase in the incidence and prevalence of the disease, which was then characterized as a public health problem. Nowadays, a decline in the prevalence, incidence and progression of dental caries has been observed globally, mainly in developed countries and in those in process of development (Fejerskov5 ${ }^{5}$ 1997).

In Brazil, although caries is considered one of the most prevalent diseases, a reduction in its prevalence is already noticed in epidemiological studies conducted across the country (Ferreira ${ }^{6}$, 2002). Three epidemiological surveys performed in Brazil analyzed the pattern of the country oral health. The Ministry of Health made the first one, in 1996, in 16 capitals and detected that dental caries reached a DMFT (decayed, missing and filled teeth) index of 6.65 at the age of 12 (OMS $\left.^{15}, 1991\right)$. The second survey was performed in 1993 by SESI (Industrial Social Service), and a DMFT of 4.9 was observed in the same age group. Despite of this visible reduction, the country is still far away from the goal settled by the WHO for the year 2000, which is a maximum DMFT index of 3 at 12 years old. In 1996, the Ministry of Health performed the first stage of the oral health survey. Although data were not published officially, they can be accessed in the website of the Ministry of Health (www.saude.gov.br) and showed a DMFT index of 3.07, which is equivalent to a reduction of $54 \%$ in caries prevalence considering the data obtained in 1986 and is very close to the goal established by the World Health Organization (WHO) for the year 2000 (Oliveira ${ }^{14}$, 1998).

Nowadays, the scientific knowledge permits to understand the new paradigms of dental practice, which are based on the complex etiology of caries. In this sense, the individual is evaluated in its totality and is submitted to interferences that modify its balance. Those include the dynamic of the de- and remineralization process and the knowledge that this mechanism, though physiological, is changeable and subjected to constant modifications. Considering this philosophy, it is necessary to change the criteria for diagnosing caries activity both in individual and community basis, changing from a simple and static observation of cavities to a more dynamic evaluation. That is the reason why the indices used in epidemiological surveys to diagnose the situation of dental caries in the population as well as the diagnostic criteria utilized by them have been changed in order to determine the real epidemiological situation of the population and not only the past history of the disease (Cardoso, Kramer, Rösing², 2000).

The relevance of evaluating the initial stages of dental caries is broadly reported in the literature. Sognnaes ${ }^{20}(1940)$ made a study about the importance of a detailed clinical exam of the carious lesions. The author established the observation of lesions to be of great value, denominated by him as "pre carious", and that would be extremely desirable to recognize them as the first clinical manifestation of caries because they could progress to cavities.

Amarante, Raadal and Espelid ${ }^{1}$ (1998) and Nyvad and Machiulsciene ${ }^{13}$ (1999) considered that the use of a criteria that includes non-cavitated lesions permits analysis of the dynamic nature of the disease.

Epidemiological surveys, like those of Pitts and Fyffe ${ }^{17}$ (1988); Ismail, et al. ${ }^{9}$ (1993); Fyffe $^{7}$ (1994) and Clark ${ }^{4}$ (1995) showed that initial carious lesions are more prevalent than cavitated lesions. Another advantage of inclusion of noncavitated lesions is the real evaluation of the efficacy of preventive programs based in the control and observation of lesions inactivation (Ismail, et al. ${ }^{8}, 1992$; Ismail $^{10}$, 1997).

This study intended to use an index in which the initial lesions of the carious process (active and inactive white spots) are included to perform a comparison between three different diagnostic methods to evaluate caries activity in a community basis.

\section{MATERIALS AND METHOD}

The present study involved examination of 30 elevenyear-old children selected at random in the State School Elpídio Paes, located in the district of Cristal in Porto Alegre (RS-Brazil). The sample was equally divided into males and females.

Accomplishment of this study was conditioned to the ethical principles of Resolution CNS 196/96 and all children had written authorization of their parents/caretakers to participate in the research. The research was approved by the Institutional Review Board of Lutheran University of Brazil (2001-012).

All volunteers $(n=30)$ were submitted to three clinical exams at three different moments in order to analyze the conditions of the study. The same examiner performed all examinations.

Previously to the study, intraexaminer calibration was performed in order to verify the agreement between readings of the same event and to make the result the most similar and unite as possible. The examiner is a trained dentist, with experience in the field of work and research, having the specialist and Master degrees. He made the calibration in the same conditions of the exams with 15 children at two distinct moments apart 7 days from each other. The degree of reproducibility by Kappa was 0.905 , which is considered excellent (WHO ${ }^{22}$, 1993b; Richmond ${ }^{18}$, 1995). The intraexaminer calibration was performed using the criteria established by this study regarding determination of the carious activity, named modified DMFS/dmfs (Figure 1).

At the first two moments, the participants were examined according to the methodology proposed by the $\mathrm{WHO}^{15}$ (1991) for epidemiological survey considering patient's position and lightning. However, the criteria used for diagnosis where those established by this study (modified DMFS/dmfs). The difference between the first and second exams was whether the bacterial plaque was present or not. In the first moment, the volunteers were examined without 
specific removal of plaque, although the probe was used for removal of gross amounts. At the second moment, supervised toothbrushing and dental flossing were performed previously to the exam. For both examinations, the surface was air-dried. At the third moment, the same individuals were examined in a dental chair after professional prophylaxis with brush, prophylactic fluoride paste and dental floss. The examination was made with the aid of light reflector and air syringe and was considered the ideal situation to detect carious activity.

The data obtained in each examination were not available to the next one to guarantee a basic principle of a blind research. In order to permit a more accurate diagnosis, the probe was used to remove bacterial plaque and when in doubt considering the carious activity diagnosis of a specific lesion. The periodontal probe was used to avoid damage to the dental structure, which could favor a future demineralization.

\begin{tabular}{|c|c|}
\hline ENTIRE & $\begin{array}{l}\text { Considered as the entire surface without evidence of caries, } \\
\text { treated or not. Surfaces with the following signs are } \\
\text { considered healthy: } \\
\text { Biological sealing: characterized by pigmentation in the } \\
\text { absence of soft tissue. } \\
\text { Dental fluorosis: observed in the whole dental surface and } \\
\text { symmetrically distributed in the dentition. } \\
\text { Enamel hypocalcification: white or yellow lesion, confined } \\
\text { to enamel, well delimitated, with smooth and shinny } \\
\text { surface. } \\
\text { Endogenous or exogenous pigmentations: characterized } \\
\text { by dark or brownish pigmentations with smooth and shinny } \\
\text { surface. }\end{array}$ \\
\hline ACTIVE WITHE SPOT (AWS) & $\begin{array}{l}\text { The dental surface presented clinically with a whitish } \\
\text { coloration, opaque and creasy. Considering the location, } \\
\text { the greater prevalence occurs in the occlusal surfaces. In } \\
\text { smooth surfaces, it is evident in the gingival third. }\end{array}$ \\
\hline INACTIVE WITHE SPOT (IWS) & $\begin{array}{l}\text { The surface has whitish or pigmented spots that are shiny, } \\
\text { smooth and hardened. }\end{array}$ \\
\hline ACTIVE CARIES CAVITY (ACC) & $\begin{array}{l}\text { - In enamel: there is a cavity associated to an active white } \\
\text { spot (AWS). } \\
\text { - In dentin: soft dentin tissue with a yellowish shade is } \\
\text { observed. }\end{array}$ \\
\hline INACTIVE CARIES CAVITY (ICC) & $\begin{array}{l}\text { - In enamel: there is a cavity associated to an inactive white } \\
\text { spot (IWS). } \\
\text { - In dentin: cavity with dark and hardened dentin tissue. }\end{array}$ \\
\hline RESTORED & $\begin{array}{l}\text { When a definitive restoration is present and there is no } \\
\text { active carious lesion (AWS or ACC). Teeth with artificial } \\
\text { crowns are considered restored, as well as surfaces with } \\
\text { sealants. }\end{array}$ \\
\hline CARIES REINCIDENCE & $\begin{array}{l}\text { When the surface has a restoration and at the same time } \\
\text { an active carious lesion associated. }\end{array}$ \\
\hline ABSENT & $\begin{array}{l}\text { Teeth are considered absent in the following } \\
\text { circumstances: } \\
\text { - Extracted: independent of the reason. } \\
\text { - With indication of extraction: residual roots and teeth with } \\
\text { indication of endodontic treatment } \\
\text { - Absent: teeth that have not erupted due to problems in } \\
\text { chronology or agenesis. When a posterior tooth is absent, } \\
\text { it will be considered } 5 \text { missing surfaces and when an } \\
\text { anterior tooth is absent, it will be considered } 4 \text { missing } \\
\text { surfaces. }\end{array}$ \\
\hline EXCLUDED & Teeth that did not fit in the above criteria. \\
\hline
\end{tabular}

Figure 1- Criteria used in the modified DMFS index 
The diagnosis was based on visual evaluation, which has high specificity according to some studies (Nuttal, Pitts, Fyfee $^{12}$, 1995); when necessary, it was complemented by tactile exam used as an auxiliary means for diagnosis. The intervals between the three examinations were seven days.

The data of the present study were analyzed considering the Kappa indicator between the two experimental models proposed (models to be used in fieldwork) in relation to the "gold standard", which was considered exam of the same criteria (modified DMFS/dmfs) in ideal conditions of drying and lightning (dental chair). Comparisons were performed for deciduous and permanent teeth, as well as for anterior and posterior teeth.

\section{RESULTS AND DISCUSSION}

Considering the primary proposals of this research, which were to verify the possibility of reproducing carious activity diagnosis criteria different from the traditional ones, the use of an indicator of agreement as the Kappa statistic seems to be adequate. This kind of statistic did not simply verify the percentage of agreement, but also excluded the concordance due to random, which permits greater dependability in the possible reproduction of results. The values obtained are presented in absolute numbers in which an acceptable Kappa variation is between 0.6 and 0.8 (average of 0.75 ) when calculated for each dental surface, an excellent value being above 0.8 and 1 is the value of maximum concordance (Peres, Traubert, Marcenes ${ }^{16}$, 2001).

Frequently, some arguments are arranged by researchers who emphasized the disadvantages of the diagnosis of active white spot (AWS): the difficulty of reproducibility and the need of ideal conditions that impaired the fieldwork. The present study tried to verify this situation in a sample of scholars (Fyffe ${ }^{7}$, 1994; Cardoso, Kramer, Rösing², 2000).

Figure 2 referred to the indices of concordance between the exams performed in different experimental conditions of the present study for the permanent and deciduous teeth evaluated. It was possible to observe that, in the population studied, a high level of agreement was reached (Kappa indicator greater than 0.9 in all comparisons) with the different manners of evaluation of carious activity. The presence of bacterial plaque or the subdivision between anterior and posterior teeth did not have negative impact on the reproducibility of caries diagnosis. In the composition of different criteria of Kappa Index, values ranged from 0.810 to 1.0 which is considered excellent and proved that a great calibration of the examination criteria was achieved.

It can be verified that reproducibility of carious activity diagnosis was not affected by the presence of bacterial plaque or by localization of the teeth in the arch. Although, it can be observed that, despite the index of concordance was still excellent, it was near 0.8 for the deciduous teeth with plaque when all these teeth were evaluated. Considering analyses of the anterior and posterior teeth separately, it can be inferred that the posterior teeth, which equally presented a lower Kappa indicator regarding other areas, primarily influenced the referred index. As the number of deciduous teeth is already diminished in this age, the impact of disagreement can be greater. Despite of that, one must consider the tendency that can be subtlety demonstrated by this situation, that removal of bacterial plaque could make the exam easier. The periodontal probe was used always when necessary as an auxiliary way to remove the excess plaque. This could have affected the results, but also signalize the possibility of having reproducible results despite the lack of ideal conditions (Ismail ${ }^{8}$, 1992; Kuzmina, Kuzmina, Ekstrand ${ }^{11}$, 1995).

The findings of this research have to be correlated with the epidemiological situation from where they were obtained. Porto Alegre is a city where caries reduction in the last years has been exponential (Schoenardie $\left.{ }^{19}, 1997\right)$. This for sure facilitates reproducibility because of the great number of entire surfaces encountered. However, entire surfaces also need to have a high level of reproducibility, because under or over diagnostic estimations considering this kind of condition are also a preoccupation in terms of epidemiological diagnosis and its consequences to strategies of action.

The mean modified DMFD (for males and females), obtained from data of the DMFS/dmfs, was 0.446 . The indices DMFS/dmfs were 0.80 and 1.26 for females and 0.13 and 2.06 for males, respectively. This value can be classified as very low according to the WHO criteria. It is a value similar to those found in countries as United States and agreed with the goal proposed by the WHO for the year $2000\left(\mathrm{WHO}^{21}, 1993\right)$.

\begin{tabular}{|l|l|cc|}
\hline LOCATION & PRESENCEOFPLAQUE & KERMANENTS & DAPPA \\
\hline \multirow{2}{*}{ ALL } & With plaque & 0.994 & 0.813 \\
& after supervised toothbrushing & 0.994 & 0.910 \\
ANTERIOR TEETH & With plaque & 0.996 & 1.000 \\
& after supervised toothbrushing & 1.000 & 1.000 \\
POSTERIOR TEETH & With plaque & 0.992 & 0.810 \\
& after supervised toothbrushing & 0.990 & 0.909 \\
\hline
\end{tabular}

FIGURE 2- Reproducibility indicator (Kappa) for permanent and deciduous teeth according to the presence of bacterial plaque and location in relation to the "gold standard" 
It can be verified that the population group analyzed presented low caries experience, which is in accordance with epidemiological surveys conducted in the last decade in Brazil. This observation has been attributed to a number of factors, but mainly to the fluoride largely used and incorporated in water supply and dentifrices (Carvalho, Thylstrup and Ekstrand ${ }^{3}$, 1992; Schoenardie ${ }^{19}$, 1997; Ferreira ${ }^{6}$, 2002).

According to the results, it can be considered that there was excellent concordance between the Kappa of teeth with plaque and after supervised toothbrushing and the Kappa of the gold standard (professional prophylaxis). As a matter of fact, it can be inferred that utilization of the modified DMFS/dmfs (with the inclusion of initial caries lesions) can be adequately performed without the use of a dental chair. This evidence allows application of this diagnostic criterion in schools, rural zones and where else it is desirable to evaluate the carious activity of certain populations, especially when the caries prevalence is not high. Thus, this kind of approach seems to be more accurate than the traditional one, which can also be obtained through this evaluation. However, it is already known that the numbers obtained through the modified DMFS/dmfs are about two times greater than those found with the traditional DMFS/ dmfs, similarly to what was studied by Schoenardie ${ }^{19}$ (1997). This can be explained by the fact that the traditional index did not consider active white spot lesions in the examination. Besides of that, correct evaluation of the real state of a cavity can be important in the decision making to restore it or not, as the simple presence of a cavity is not a sufficient reason to justify a restorative procedure in the new paradigms of Dentistry.

\section{CONCLUSION}

According to the results, it was possible to conclude that the three diagnostic methods for carious activity presented conditions of reproducibility in the study population and can be considered one more epidemiological tool in the design of population surveys considering dental caries.

\section{REFERENCES}

1- Amarante E, Raadal, M, Espelid, I. Impact of diagnostic criteria on the prevalence of dental caries in Norwegian children aged 5, 12 and 18 years. Community Dent Oral Epidemiol. 1998;26:87-94.

2- Cardoso L, Kramer PF, Rosing CK. Cárie dentária em crianças: levantamento epidemiológico através do índice CPOS modificado. Rev ABOPREV. 2000;3:32-9.

3- Carvalho JC, Thylstrup A, Ekstrand KR. Results after 3 years of non-operative occlusal caries treatment of erupting permanent first molars. Community Dent Oral Epidemiol. 1992;20:187-92.

4- Clark DC. Effects of lifelong consuption of fluoridated water or use of fluoride supplements on dental caries. Community Dent Oral Epidemiol. 1995;23:20-4.
5- Fejerskov O. Concepts of dental caries and their consequences for understanding the disease. Community Dent Oral Epidemiol. $1997 ; 25: 5-12$

6- Ferreira SH. Prevalência de cárie em pré-escolares de escolas municipais de educação infantil de Canoas - RS. Canoas; 2002. [Dissertação de Mestrado - Faculdade de Odontologia da ULBRA].

7- Fyffe HE. Evaluation of enhanced dental epidemiological criteria for caries prevalence surveys. J Dent Res. 1994;73:821-6.

8- Ismail A, Vrodeur JM, Gagnon P, Payette M, Picard D, Hamalian $\mathrm{T}$, et al. Prevalence of non-cavitated and cavitated carious lesions in a random sample of 7-9 year old schoolchildren in Montreal, Quebec. Community Dent Oral Epidemiol. 1992;20:250-5.

9- Ismail A I, Shoveller J, Langille D, Macinnis W A, Mcnally M. Should the drinking water of Truro, Nova Scotia be fluoridated? Water fluoridation in the 1990's. Community Dent Oral Epidemiol. 1993;21:118-25.

10- Ismail A. Clinical diagnosis of precavitated carious lesions. Community Dent Oral Epidemiol. 1997;25:13-23.

11- Kuzmina IN, Kuzmina E, Ekstrand KR. Dental caries among children form Solt Sevsky a district in Moscou, 1993. Community Dent Oral Epidemiol. 1995;26:266-70.

12- Nuttal NM, Pitts NB, Fyffe HE. Assesment of reports by dentists of their restorative treatment thresholds. J Dent Res. 1993;21:273-

13- Nyvad B, Machiulsciene V. Reliability of a new caries diagnostic system differentiating between active and inactive caries lesions. Caries Res. 1999;33:252-60.

14- Oliveira AGRC. Levantamento epidemiológico em saúde bucal $1^{\text {a }}$ etapa - cárie dental, 1996. Relatório Paralelo. 1998. Disponível em: http://www.angelonline.cjb.net

15- OMS. Levantamento epidemiológico básico de saúde bucal. Manual de Instruções. Brasília: OMS; 1991.

16- Peres MA, Traubert J, Marcenes W. Calibração de examinadores para estudos epidemiológicos de cárie dentária. Cad Saúde Pública 2001;17:153-9.

17- Pitts NB, Fyffe HE. The effect of varying diagnostic thresholds upon clinical caries data for a low prevalence group. J Dent Res. 1988;67:592-6.

18- Richmond S. Calibration of dentists in the use of occlusal indices. Community Dent Oral Epidemiol 1995; 23:173-6.

19- Schoenardie AB. Avaliação da prevalência de cárie e de gengivite em escolares de Porto Alegre em 1975 e em 1996. Porto Alegre; 1997. [Dissertação de Mestrado - Faculdade de Odontologia da UFRGS].

20- Sognnaes RF. The importance of a detailed clinical examination of carious lesions. J Dent Res. 1940;19:11-5.

21- World Health Organization. Oral dental health global indicators for 2000: dental caries level at 12 years. Geneve, WHO; 1998. 34p.

22- World Health Organization. Calibration of examiners for oral health epidemiological surveys. Geneve, WHO; 1993. 18p. 